\title{
IDENTIFICATION OF AFFECTED HIGH-ALTITUDE WETLANDS IN THE NORTH CHILE USING LARGE LANDSAT TIME SERIES
}

\author{
D. Castillo ${ }^{1}$, A. Russell ${ }^{1}$, V. Caquilpan ${ }^{1}$, S. Elgueta ${ }^{1}$ \\ ${ }^{1}$ Superintendence of Environment, Santiago, Chile - (denisse.castillo, ariel.russell, victor.caquilpan, sebastian.elgueta)@ sma.gob.cl
}

KEY WORDS: Change detection, Landsat, BFAST Monitor, wetlands, monitoring.

\begin{abstract}
:
High-Andean wetlands from northern Chile are considered worldwide biodiversity hot spots, however, they are subdued to high anthropic pressure. The monitoring of state variables, such as vegetation, allows to know the ecosystem's global condition, which could be assessed by the analysis of spectral vegetation indices. The main goal of this paper was to detect changes in the highAndean wetland vegetation, with remote sensing tools, to focalize surveillance efforts and the use of resources from environmental agencies. NDVI time series were constructed spanning from 1986 to 2019 based on Landsat data, which were analyzed based on the vegetation change detection using BFAST Monitor method. Detected changes were categorized to highlight certain types of changes that were considered more relevant. Wetlands were separated in two rankings (A and B) based on detected changes and territorial context. From 5,622 wetlands, 81 were categorized into group A and 510 into group B. One affected wetland was used as study case to assess the method's efficiency, being able to detect changes and assign a relative importance to the case. It is shown that the proposed method has the capacity to detect vegetation degradation processes in high-Andean wetlands and could improve in the efficiency and effectiveness of the environmental agencies control labors over these ecosystems.
\end{abstract}

\section{INTRODUCTION}

High-Andean wetlands located in northern Chile have a high ecological value due to the high species richness that can be found in these ecosystems because of the high spatial heterogeneity, being considered biodiversity hotspots (Ahumada, Faúndez, 2009). Also, they provide ecosystem services which are very important for local communities, such as hydrological cycle regulation and food supply (RamsarMMA, 2015, ten Brink et al., 2013).

Their azonal distribution is associated to temporally or permanently saturated soil strata due to local hydrogeological conditions. This makes them highly susceptible to changes in hydrological regimes of the systems that feed them, which are considered one of the main drivers of change (Ahumada et al., 2011; Ahumada, Faúndez, 2009). The latter is very relevant due to high levels of anthropic pressure that many of these wetlands are exposed to due to water extraction for local economic activities, such as mining and agriculture, among others. Therefore, wetland monitoring is fundamental to act in a timely manner against possible actions that could result in negative impacts to them. In this sense, the role of environmental control institutions, as Superintendence of Environment (SMA, from its Spanish initials) is crucial, since it oversees the compliance with environmental regulations and commitments acquired by the owners of projects and productive activities in order to avoid negative environmental impacts. However, it is necessary to consider the limited supervising resources, which complicate the establishment of an adequate spatial-temporal coverage control that would provide a full understanding of all the regulated aspects related to the ecosystem's health. Instead, they are only analyzed based on specific inspections caused by complaints and to a lesser extent by scheduled inspections.

A wetland's survey can be done at different spatial-temporal scales, which show different aspects of its dynamic and structure (Ahumada et al., 2011). Currently, the United States Environmental Protection Agency (EPA) defines three levels for wetland monitoring and assessment. Level 1 considers a landscape level vision based on large-scale approaches, generally through remote sensing techniques, while levels 2 and 3 take into account brief and intensive in-situ evaluations, respectively (EPA, 2019). The two latter require important amounts of logistics and resources to be executed and sustained, limiting their applying to specific study cases. Considering this, the identification of "state variables" allows to study the wetlands global condition without the need for a deep analysis, being the vegetation one of the main state variables in wetland ecosystems because it is directly affected by changes in hydrological availability (CEA, 2006), and has been widely studied by means of spectral indices obtained from satellite imagery (Kayastha et al., 2012, Hansen et al., 2016). In present days, satellite remote sensing is a true and reliable option for acquiring surface information from large portions of the earth systematically. Besides, there is an increasing number of free data available online for public access in various spatial and temporal scales, turning remote sensing into an ideal tool for developing low-cost applications for environmental monitoring to be used by environmental agencies with limited resources.

There are a number of international examples in the matter, such as DETER system in Brazil, which allows to generate deforestation alerts in the Amazonas (Diniz et al., 2015), a coastal monitoring system for detecting hydrocarbon spills in Argentina (CONAE, 2019) and other global scale initiatives such as the Global Wetland Observation System GWOS which emerged from the 2007 Ramsar convention (GEO BON, 2019). In general terms, national wetland monitoring initiatives are limited to particular cases or projects restricted to national parks and reserves. Nevertheless, the inclusion of remote sensing tools in wetland monitoring could help to develop a continuous and permanent survey that includes much of the high-Andean wetlands that exist in northern Chile.

This work aims to use satellite imagery to provide the environmental institutions with a tool that will help to focalize control efforts and act in timely manner against possible negative impacts derived from anthropic factors over high- 
Andean wetlands that haven't been detected by traditional means such as complaints and inspections.

\section{OBJECTIVE}

To create a methodology for the monitoring of vegetation in high-Andean wetlands in terms of changes generated by potential anthropic impacts, which will lead to prioritize and focus environmental agencies control efforts.

\section{METHODOLOGY}

\subsection{Study area}

The study area (Figure 1) corresponds to all of the high-Andean wetlands located in Arica and Parinacota, Tarapacá, Antofagasta and Atacama regions that has been registered by the Environment Ministery of Chile in 2015 that are located over 2,000 of altitude (CIREN 2013), which sum up to 6,706 wetlands.

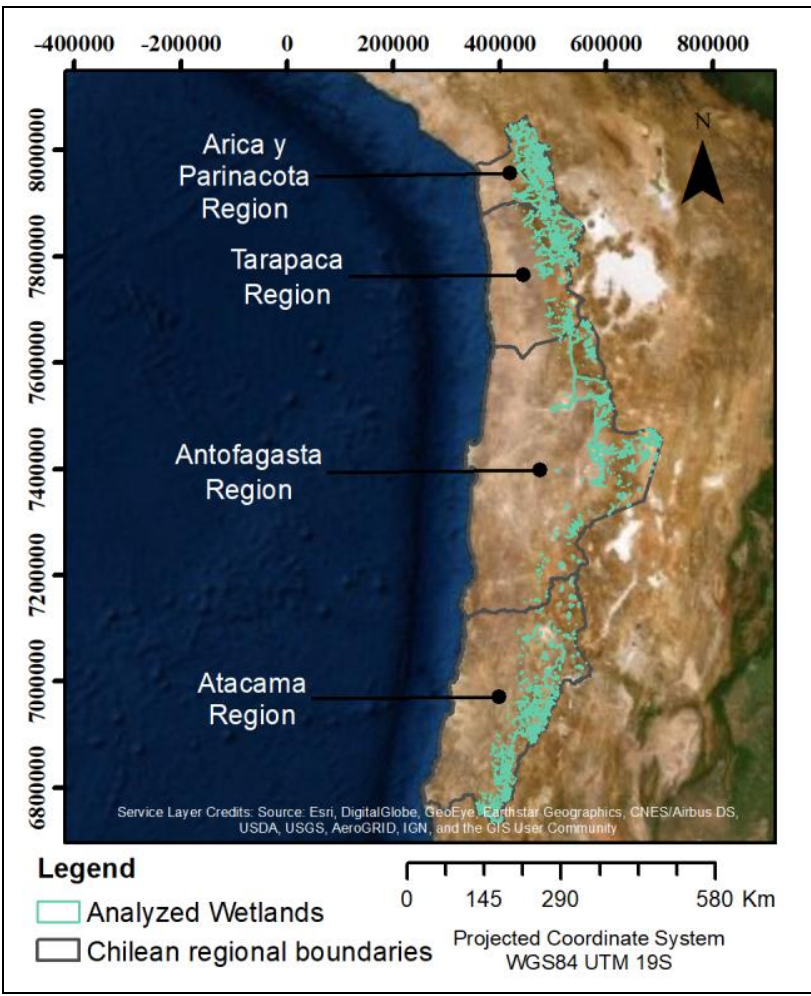

Figure 1. Study Area.

\subsection{Satellite imagery}

Satellite imagery used in this research corresponds to Landsat data from 1986 to 2019. Specifically, we used the 30m Surface Reflectance product, choosing only Collection 1 Tier 1 data from TM5 and ETM+ sensors aboard Landsat 5 and 7 platforms. No OLI imagery was included as to preserve spectral and radiometrical consistency among images. Only summer scenes (December to March) were considered for the study since it's the time of year with the highest vegetation vigor, allowing a better study of this variable and to avoid snow cover in the higher reaches. Scenes with more than $30 \%$ of cloud cover were excluded from the analysis, and subsequent cloud and saturated pixels masking using QA bands were performed to enhance data quality. A thermal band-based filter was also applied to reduce confusion between salt flats and clouds in the area. The vegetation index was calculated for each scene, grouping them afterwards by summer season and obtaining the summer median value for each pixel, which was chosen as the representative value for each year.

\subsection{Time series construction}

The creation of time series is based on generating an index that is consistent in time and ordered chronologically. In remote sensing, the time series are pixel-based and represent the variation of a certain variable in a fixed geographical location (a same pixel) in time for a set of particular images (each image is a different date).

3.3.1 Generation of vegetation index: Time series for vegetation monitoring are based on the Normalized Difference Vegetation Index (NDVI) (Rouse et al., 1974), which is used as a proxy for vegetation vigor and/or cover and has been proven to be precise in the estimation of vegetation cover for arid zones (Barati et al., 2011).

3.3.2 Pixel selection for analysis: In a first approach, the study area was based on a mask generated using polygon products from the 2015 Wetland Inventory form the Ministry of Environment of Chile, plus a $100 \mathrm{~m}$ buffer to ensure the selection of all pixels that represent wetland vegetation. The NDVI was subsequently calculated for these pixel series.

Additionally, a data availability filter was applied to the time series to include only pixels with enough data and that had vegetation in the period between 1986 and 1999. This period was defined as the base (or historic) period for the change analysis (that will be explained in the next section) because it allows to have a minimum amount of observations for the training of the model, and due to the difficulty of the environmental authority to act upon events that happened before 2000. In order to do so, pixels were selected based on two criteria:

1. That pixel time series count with at least 10 observations in the base period for the generation of a trend model.

2. That the NDVI median of the base period is above a threshold that can be considered vegetation. Based on observation performed in the study area, the threshold value was set to 0.08 as to include areas with very low vegetation cover, a situation that was observed in some wetlands in the area

After filtering, 1,048 wetlands were excluded from the analysis because they did not have vegetation to analyze, leaving a total of 5,622 to study.

\subsection{Time series analysis}

BFAST Monitor algorithm was used to detect changes in the time series, which is based on the "Break detection For Additive Season and Trend" algorithm (BFAST) (Verbesselt et al, 2012). The method consists on the generation of a model that represents vegetation behavior in the time based on a "historic" period (1986 - 1999 in this research) that is considered stable, and evaluates if new data, since 2000 , considered as monitoring period), behaves in the same manner. It is based on a linear trend and a harmonic season to represent vegetation phenological fluctuations. Only the linear trend was used in the present research because only one scene per season was considered. The algorithm was chosen due to its ease of use, 
without the need of setting change thresholds. This is very useful in a high range of environmental conditions, wide levels of NDVI fluctuation and various types of changes. Besides, it is not affected by gaps in the time series, avoiding the use of imputations methods. The model's output corresponds to the year of change and magnitude.

\subsection{Results generation at pixel level}

With the aim to detect the wetlands that experienced the most relevant changes and help to eliminate false change detections due to the own methods limitations, a pixel-level categorization was done based on the magnitude and slope of the historic period and monitoring period linear trends. The year of change was not considered, however this feature is relevant in subsequent steps to relate relevant vegetation changes with natural or anthropic events that had taken place nearby. Besides, only negative changes were considered in the analysis given that the aim of the study is to detect harmful impacts on wetlands (decrease in vigor or vegetation cover).

As a first step to pixel categorization, the linear trends behavior for the historic and monitoring period for every pixel were classified into positive, null or negative. Based on a series of possible combinations (historic/monitoring period), they were assigned a value between 0 and 3 , as show on Table 1 . This allows to prioritize certain changes that are more relevant in terms of environmental inspections, as well as mitigate the effect of false change detections and inflated change magnitudes due to the projection of increasing trends since the historic period that, when not met, are detected as possible significant changes (DeVires et al, 2015).

\begin{tabular}{|cc|}
\hline Historic period / monitoring period & Category \\
\hline Null/Null, Positive/Positive & 0 \\
Negative/Null, Negative/Positive & 1 \\
Null/Positive, Negative/Negative, Positive/Null & 2 \\
Null/Negative, Positive/Negative & 3 \\
\hline
\end{tabular}

Table 1. Categorization based on slopes of linear trends

Afterwards, the change magnitudes were classified into 5 categories according to their position in the quartile (Q), including atypical values. Negative change magnitudes were converted to positive values. The data distribution showed atypical values above the upper quartile, which were considered the most abrupt changes and were classified as category 5 . The rest of the classification is shown in Table 2.

\begin{tabular}{|ccc|}
\hline Limit values & $\begin{array}{c}\text { Magnitude } \\
\text { range }\end{array}$ & Category \\
\hline Values < Q1 & $0-0,018$ & 1 \\
Q1 - Q2 & $0,018-0,033$ & 2 \\
Q2 - Q3 & $0,033-0,072$ & 3 \\
Q3 - (Q3 + 1.5 $\times$ RIC) & $0,072-0,154$ & 4 \\
Atypical Values > (Q3 + 1.5 & $0,154-99$ & 5 \\
IQR (1)) & & \\
\hline
\end{tabular}

Table 2. Categorization according to change magnitude.

Finally, the slope of linear trends and magnitude classification were combined to generate 7 final categories as shown in Table 3. The highest values represent the most important pixels.

\begin{tabular}{|ccc|}
\hline Slope categories & $\begin{array}{c}\text { Magnitude } \\
\text { categories }\end{array}$ & $\begin{array}{c}\text { Change } \\
\text { Category }\end{array}$ \\
\hline 3 & 5 & 7 \\
3 & $3-4$ & 6 \\
3 & $1-2$ & 5 \\
2 & $4-5$ & 4 \\
2 & $1-3$ & 3 \\
1 & $1-5$ & 2 \\
0 & $1-5$ & 1 \\
\hline
\end{tabular}

Table 3. Change categorization.

\subsection{Results generation at wetland level}

Results generation at wetland level consisted in collecting all data that could allow to identify each unit's state (pixel information) and its local context. Three main aspects were considered for estimating change severity: affectation, causality and relevance, which are explained next.

3.6.1 Affectation: Affectation for each wetland is defined by their pixel's features. On this way, the following indicators were generated per wetland:

1. Number of pixels in category 6 and 7 , considered the most relevant.

2. Percentage of pixels that changed from category 6 and 7 to other category, with respect to the total amount of pixels for each wetland.

3.6.2 Causality: As a way of integrating local context, the distance to surface and groundwater extraction points was included (Alvares-Garreton et al, 2018). This was done to relate anthropic causes to eventual degradation processes given the range of action of environmental control institutions. The used criteria were the following:

1. Wetlands with 1 or more groundwater extraction at less than $5 \mathrm{~km}$, given that they belong to the same basin.

2 . Wetlands with 1 or more surface or groundwater extraction points at less than $10 \mathrm{~km}$, given that they belong to the same basin and that they are located upstream from the wetland's lower point.

3.6.3 Relevance: Relevance was defined based on if wetlands were located in some of the following interest zones: Site under official protection (2), Indigenous Development Area (CONADI, 2019) and/or Restriction Area of Prohibition Zone (DGA, 2019). These zones were used because they have high level of environmental and social protection in the country.

\subsection{Detection and sorting of relevant cases}

Two rankings (A and B) were generated from the outputs when applying affectation, causality and relevance criteria. Ranking A was defined prioritizing the area and proportion of affectation in the wetland, while Ranking B was defined based on affected area independently from the percentage of change. This was done to include large wetlands with high absolute surfaces of change but little in terms of the whole area. Used criteria are detailed in Table 4: 


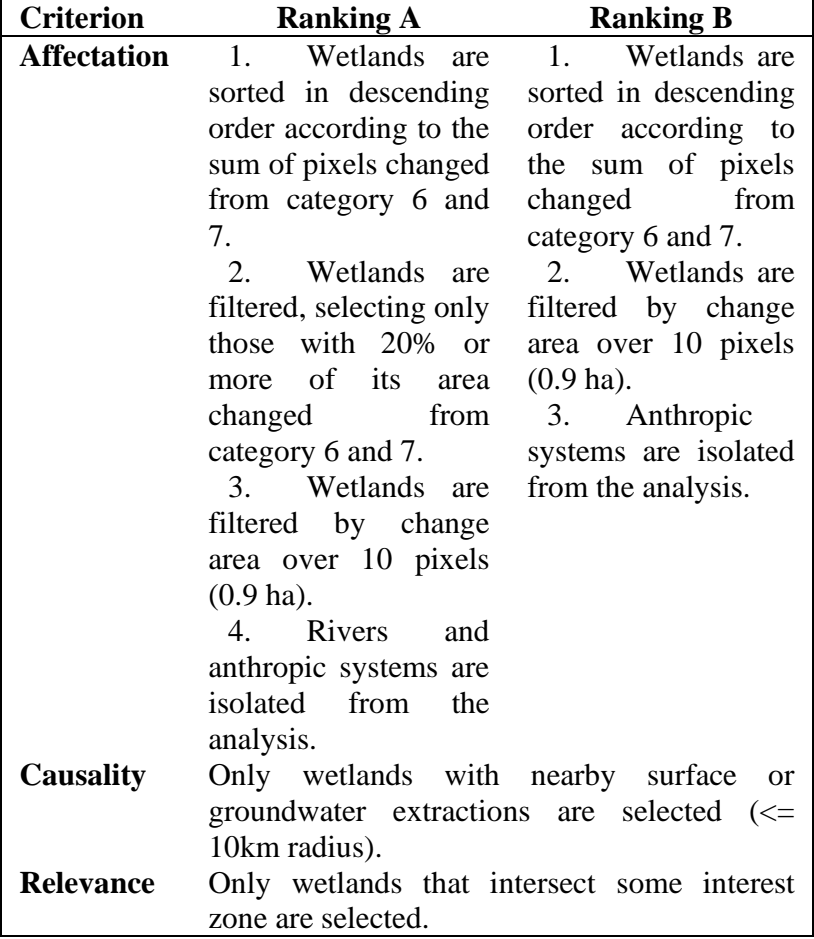

Table 4. Criteria for ranking generation.

\section{RESULTS AND DISCUSSION}

From a total of 5,622 wetlands analyzed, $87 \%$ had at least 1 pixel with some level of change, representing 26,050 ha of potentially affected wetlands across the monitoring period. In terms of relevant changes (categories 6 and 7), they represent $50 \%$ of the analyzed wetlands with 7,320 ha of potentially relevant change ( $3.8 \%$ of the total area).

Based on the given methodology, Rankings A and B were created. 81 wetlands were categorized into ranking A while 510 in ranking $\mathrm{B}$, significantly reducing the numbers of wetland to analyze and enabling to focalize inspection efforts by starting by the top wetlands in each ranking. The utility of having two rankings lie in the case of large wetlands with high absolute affected areas that don't fall in ranking A because they don't fulfill the percentage of change condition (area affected $<20 \%$ of total area) defined in this ranking. So, leading wetlands in ranking $\mathrm{B}$ are considered of similar importance as those leading ranking $\mathrm{A}$, which present a greater affected area.

In order to evaluate the methodology, a study case was conducted with the wetlands of Valle Ancho, in Atacama Region, which were inspected by the Superintendence of the Environment (SMA by its initials in Spanish) in 2015 in the context of a sanctioning process against Maricunga Mining Company and its Refugio mining project, which was finally closed due to the generation of environmental damage (SNIFA, 2019). This thesis was supported via the analysis of vegetation index time series, which showed a drying trend in the vegetation that was associated with groundwater extraction. This study considered the affection of 3 wetlands which correspond to Valle Ancho 2 and two nameless wetlands, which are identified by the ID: HU-OT-4024, HU-OT-4023 and HU-OT-4025 (Figure 2).

As a result of the categorization and applying criteria filters and ranking generation, wetlands HU-OT-4024, HU-OT-4023 and
HU-OT-4025 were located in positions 6, 13 y 27 of ranking A and 29,85 and 168 on ranking $B$, respectively.

In this case, the algorithm used in this work detects changes in almost $50 \%$ of the study area, with $22.6 \%$ considered as relevant changes (categories 6 and 7). Also, wetland HU-OT4024 presents a higher number of pixels detected in categories 6 and 7 (407 pixels) than wetland HU-OT-4023 (111 pixels), which has a greater proportion of category 4 pixels (139). This can be explained by the temporality of the changes happened in wetland HU-OT-4023, because the degradation trends were present before the monitoring period began, thus creating a negative-negative trend slope combination and being classified in category 4 (Table 3 ). On the other hand, wetland HU-OT4024 had null to positive trends during the historic period, starting to showing evident degradation signals after 2000 and thus being classified into categories 6 and 7. Figure 3 shows examples of the behavior of the analyzed time series and change detection for a pixel belonging to each one of the defined categories.

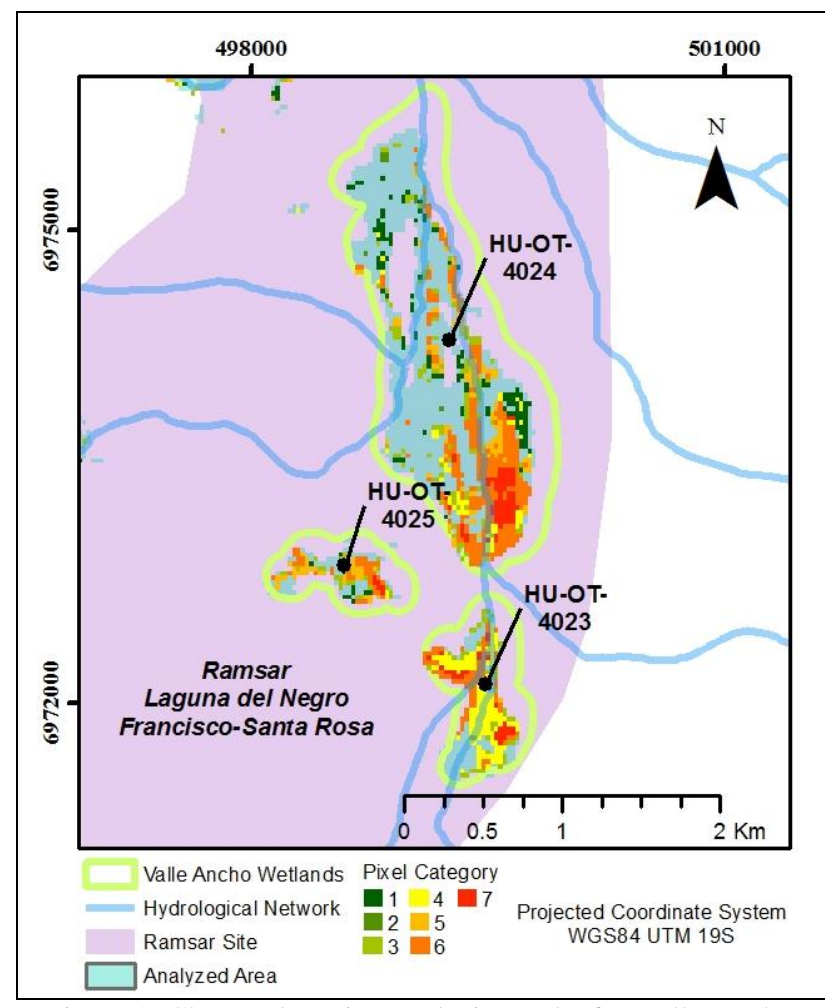

Figure 2. Change detection analysis results for Valle Ancho wetlands.

This shows that the pixel categorization according to the type of change allows to focus efforts on wetlands with more recent degradation processes. These are more relevant for the environmental control institutions since it eases to detect possible causality and gives a wider range of action to apply measures needed to revert and/or mitigate negative effects of this changes on wetlands.

Also, the detection of these cases in such a broad universe of cases implies that the method can give warnings on cases as complicated as Valle Ancho or worse. In this way, ranking information can be used to detect similar cases that haven't been identified through traditional methods, and year of change could be used to relate changes with local events happening in the area. 
It is important to state that the information generated by this method is indicative and aims to generate alarms on wetlands that are potentially being affected by water extraction or other factors. Each case should be analyzed individually in order to build a hypothesis about the possible factors or activities that could cause changes in each wetland through detailed on-site data collection.

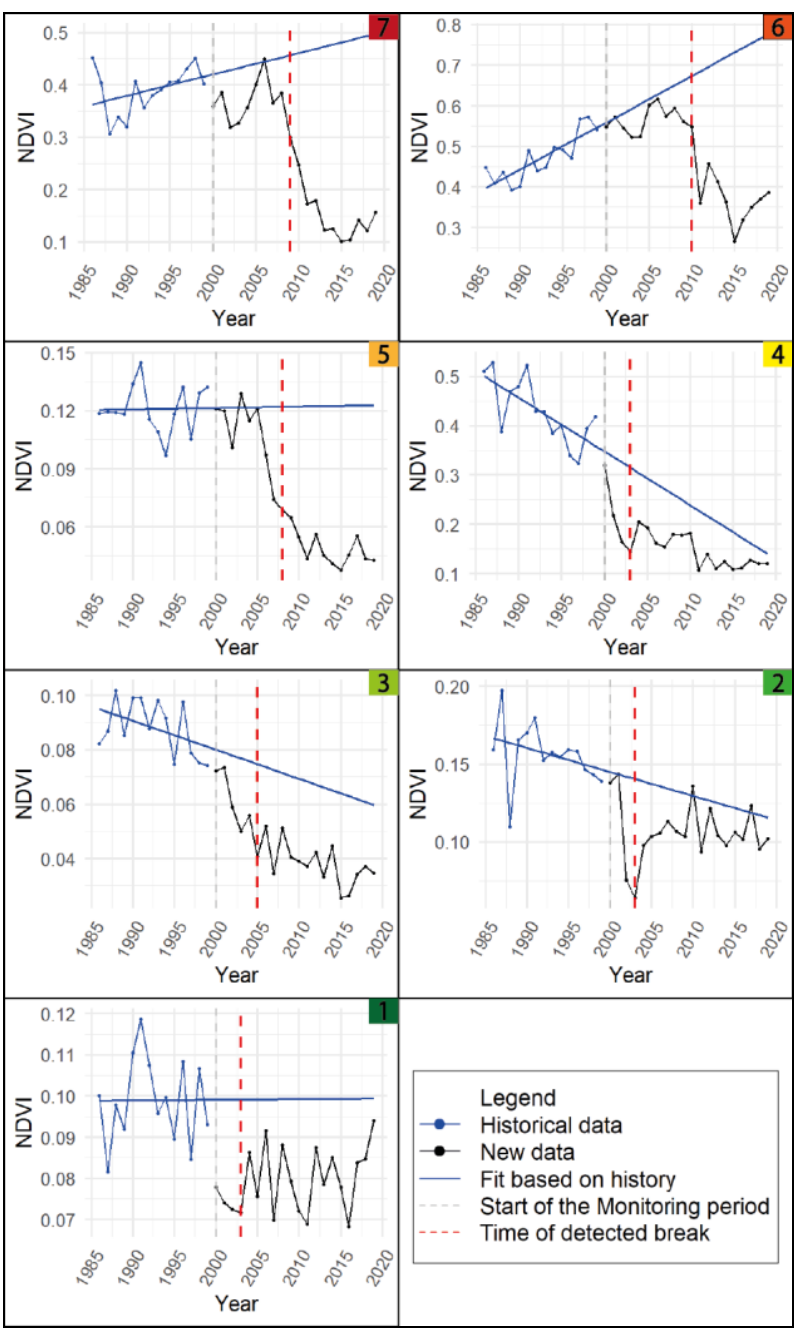

Figure 3. Example of the behavior of pixel time series in the Valle Ancho wetland according to change category.

\section{CONCLUSION}

The presented method proved to be able to detect both abrupt and gradual degradation processes in high-Andean wetland vegetation in an automatized way using remote sensing tools. In this sense, it represents a great opportunity for expanding the observation range and focusing efforts for environmental agencies related with the vigilance of high importance ecosystems.

The generation of an affectation, causality and relevance ranking allows to focalize efforts and increase efficiency and effectiveness of the use of resources from the environmental institutions in a zone where in-situ inspections are operationally and logistically costly. Also, it has a positive effect due to the deterrent effect of having a permanent monitoring on these ecosystems located in extreme zones and opens the possibility to create alerts over degradation processes that complement those generated by traditional methods like complaints and onsite inspections.

On the other hand, increasing availability of high-performance cloud computing tools and free satellite databases have permitted the development of satellite big data applications, like this project, without the need of owning high cost equipment. In this way, new opportunities arise for the development of tools that could increase efficiency of public entities control labors without a significant increase in operational costs.

It is important to state that one of the possible method's limitation is that it is only useful for detecting variations in vegetation vigor/cover and no other degradation events like variations in vegetation's composition and configuration caused by changes in the hydric regime. These changes could be undetected when using the NDVI, so the use of complementary indices related to the vegetation's hydric content or denser time series that include more than one scene per year so that phenological changes can be detected are recommended. Great improvement opportunities in terms of territorial context inputs are detected, like the need for a more detailed and updated water extraction cadastre in the area and better groundwater systems information at regional level. Other aspects can also be included, like the spatial aggregation of changes as an input for case prioritization.

Finally, an in-situ validation campaign is sought to be done in the future to detect strong points and limitations of the proposed methodology and increase the accuracy of the results and improve the tool in the context of high-Andean wetlands.

\section{REFERENCES}

Ahumada, M., Aguirre, F., Contreras, M., Figueroa, A., 2011. Guía para la conservación y seguimiento ambiental de humedales andinos. Biblioteca Digital CEDOC-CIREN. http://bibliotecadigital.ciren.cl/handle/123456789/26045 November 2019).

Ahumada, M., Faúndez, L., 2009. Guía Descriptiva de los Sistemas Vegetacionales Azonales Hídricos Terrestres de la Ecorregión Altiplánica (SVAHT). Biblioteca Digital CEDOCCIREN. http://bosques.ciren.cl/handle/123456789/6189 (1 Novembrer 2019).

Alvarez-Garreton, C., Mendoza, P., Boisier, J.P., Addor, N., Galleguillos, M., Zambrano-Bigiarini, M., Lara, A., Puelma, C., Cortes, G., Garreaud, R., McPhee, J., Ayala, A. 2018. The CAMELS-CL dataset - links to files. PANGAEA. doi.org/10.1594/PANGAEA.894885.

Barati, S., Rayegani, B., Saati, M. Sharifi, A., Nasri, M., 2011. Comparison the accuracies of different spectral indices for estimation of vegetation cover fraction in sparse vegetated areas. The Egyptian Journal of Remote Sensing and Space Science. 14(1):49-56. https://doi.org/10.1016/j.ejrs.2011.06.001. Centro de Ecología Aplicada (CEA), 2006. Conceptos y criterios para la evaluación ambiental de humedales. Biblioteca Digital

CEDOC-CIREN. http://bibliotecadigital.ciren.cl/handle/123456789/697 November 2019).

Centro de Información de Recursos Naturales (CIREN), 2013. Caracterización de Humedales Altoandinos para una gestión sustentable de las actividades productivas del sector norte del 
país. Informe Final. Repositorio Digital CORFO. http://repositoriodigital.corfo.cl/handle/11373/2681 (4 June 2019).

Comisión Nacional de Actividades Espaciales (CONAE), 2019. Monitoreo costero para la detección de derrames de hidrocarburos. Ministerio de Educación, Cultura, Ciencia y Tecnología. Gobierno de Argentina. https://www.argentina.gob.ar/ciencia/conae/aplicaciones-de-lainformacion-satelital/monitoreo-costero (1 November 2019).

Corporación Nacional de Desarrollo Indígena, 2019. Capa: dn_Áreas_desarrollo_indígenas_act_2017. Sistema Integrado de Información CONADI. http://siic.conadi.cl (19 June 2019).

DeVries, B., Verbesselt, J., Kooistra, L., Herold, M., 2015. Robust monitoring of small-scale forest disturbances in a tropical montane forest using Landsat time series. Remote Sensing of Environment. 161: 107-121. https://doi.org/10.1016/j.rse.2015.02.012.

Díaz, I., 2019. Monitoreo satelital en humedales del SNASPE, Corporación Nacional Forestal. Seminario Innovaciones tecnológicas de las economías APEC para la evaluación y protección de los ecosistemas forestales, 26 de febrero de 2019, Talca,

Chile. http://www.conaf.cl/seminarioAPEC/dia1_09_ppt_Ignacio_Dia z.pdf (1 November 2019).

Diniz, C., Souza, A., Santos, D., Dias, C., Luz, N., Moraes, D.,Maia, J., Gomes, A., Narvaes, I., Valeriano, D., Maurano, P., Adami, M., 2015. DETER-B: The New Amazon Near RealTime Deforestation Detection System. IEEE Journal of Selected Topics in Applied Earth Observations and Remote Sensing, 8(7), 3619-3628. doi:10.1109/jstars.2015.2437075.

Dirección General de Aguas (DGA), 2019. Capa: Areas_de_Restricción_y_Zonas_de_Prohibición_Enero_2019. https://dga.mop.gob.cl/estudiospublicaciones/mapoteca/ $(19$ June 2019).

Group on Earth Observations Biodiversity Observtion Network (GEO BON), 2019. Global Wetlands Observing System (GWOS). https://geobon.org/global-wetlands-observing-systemgwos/ (1 November 2019).

Hansen, M., Krylov, A., Tyukavina, A., Potapov, P., Turubanova, S., Zutta, B., Suspense, I., margono, B., Stolle, F., Moore, R., 2016. Humid tropical forest disturbance alerts using Landsat data. Environmental Research Letters, 11(3), 034008. doi:10.1088/1748-9326/11/3/034008.

Kayastha, N., Thomas, V., Galbraith, J., Banskota, A., 2012. Monitoring Wetland Change Using Inter-Annual Landsat TimeSeries Data. Wetlands. 32(6):1149-1162. doi: 10.1007/s13157012-0345-1

Ramsar-Ministerio del Medio Ambiente (MMA), 2015. Humedales: ¿por qué cuidarlos? Ficha Informativa 1. http://www.mma.gob.cl/correosvirtuales/humedales/doc/Por_qu e_cuidar_los_humedales.pdf (1 November 2019).

Rouse, J., Haas, H., Sehell, A., Deering, W., 1974: Monitoring vegetation systems in the Great Plains with ERTS. NASA. Goddard Space Flight Center 3d ERTS-1 Symp., Vol. 1, Sect. A, 309-317.
Sistema Nacional de Información de Fiscalización Ambiental (SNIFA), 2019. Registro Público de Sanciones. Expediente D014-2015. Superintendencia del Medio Ambiente. Gobierno de Chile. http://snifa.sma.gob.cl/v2/RegistroPublico/Ficha/1215 (1 November 2019).

Tapia, G., 2019. Sistema de Monitoreo de Extracción y Cosecha Forestal (LEMU), Corporación Nacional Forestal. Seminario Innovaciones tecnológicas de las economías APEC para la evaluación y protección de los ecosistemas forestales, 27 de febrero de 2019, Talca, Chile. http://www.conaf.cl/seminarioAPEC/dia2_02_ppt_Gonzalo_Ta pia.pdf (1 November 2019).

ten Brink P., Russi D., Farmer A., Badura T., Coates D., Förster J., Kumar R., Davidson N. 2013. La Economía de los Ecosistemas y la Biodiversidad relativa al agua y los humedales. Resumen ejecutivo. https://www.ramsar.org/sites/default/files/documents/library/tee b_waterwetlands_execsum_2013-sp.pdf (1 November 2019).

United States Environmental Protection Agency (EPA). 2019. Wetlands Monitoring and Assessment. https://www.epa.gov/wetlands/wetlands-monitoring-andassessment (1 November 2019).

Verbesselt, J., Zeileisb, A., Herolda, M., 2012: Near real-time disturbance detection using satellite image time series. Remote Sensing of Environment. 123, 98-108. 